\title{
Factors Affecting the Acceptability of Online Degrees: Evidence from Two Arab Countries
}

\author{
https://doi.org/10.3991/ijet.v11i12.6022 \\ Alaa Sadik \\ South Valley University, Qena, Egypt
}

\begin{abstract}
The purpose of this study was to investigate the acceptance of degrees earned wholly online and to define the factors that affect the perceived value of these degrees in two Arab countries; Egypt and Oman. To achieve this purpose, a societal acceptance of online distance education degrees questionnaire was developed and administered online to a sample of $\mathbf{4 7 9}$ participants from different business sectors in Egypt and Oman. The responses to the rating scales and open-ended questions were organized, analyzed, and coded to address pattern of responses. Quantitative data and open-ended responses showed that the overall perception expressed by respondents was that online distance education was viewed as inferior to traditional education, and degrees earned online are not similar to ones earned in traditional settings in terms of credibility and quality. The ANOVA tests were used to analyze the differences among groups of participants and their acceptance of online degrees. Overall, responses indicated that no significant differences existed among participants. Many aspects of online degrees, such as interaction between students and the instructor, credibility with employers, admission regulations, and quality of learning outcomes have been criticized from many perspectives.
\end{abstract}

Index Terms-societal acceptance, Arab society, online distance education, e-learning, quality of education, credibility of education.

\section{BACKGROUND}

Historically and culturally, the Arab countries have many features in common, in particular from the linguistic and tradition standpoints; however, it is in many respects highly inconsistent in terms of population, national income, prosperity, stability, infrastructure, literacy rate, and information resources. The estimated overall population of the Arab countries in 2010-2011 was just over 360 million with over half under 25 years of age. Almost a quarter of the Arab world live in the most populated country of the region, Egypt. The number of Internet users in 2011 was estimated to be 86 million users (United Nations, 2011). Although distance education has a short history in the Arab world, for many, within the last ten years, the interest in distance education in the Arab world was enhanced dramatically as a result of the changes in society, culture, economy, employment, and information technology (AlHarthi, 2005). This interest resulted in a remarkable increase in the distance education programs and degrees offered by many traditional and distance education universities in many Arab countries (Mohamed, 2005).

\section{ONLINE Distance EdUCATION In The ARAB WORLD}

Many efforts have been made in Egypt, Kuwait, Saudi Arabia and Lebanon to provide off-campus programs by traditional universities providing conventional and distance education simultaneously. The increased demand for and access to online learning is evident when examining the escalating number of online programs now available (Adams, 2016). Many universities have established open education units (e.g., the Open Learning Center at Cairo University in Egypt), awarding bachelor, and master degrees through distance education mode in a variety of disciplines. However, with the increased public interest in distance education, new distance education universities have been established to deliver fully distance education programs using different types of media and technologies (e.g., printed materials, video tapes, and interactive multimedia CDs).

The unique example in this regard is the Arab Open University (AOU), which was established in 1999, in cooperation with the British Open University (OU), with the main campus in Kuwait and 6 branches in Saudi Arabia, Egypt, Jordan, Lebanon, Bahrain, and Oman. Making use of modern information and communication technologies, AOU aimed to make higher education and continuing education accessible to every willing and capable Arab citizen (Arab Gulf Program For United Nations Development Organizations, 1999). In response to this development, distance education has become one of the important alternatives for those who could not attend or enroll in conventional universities. This rapid development in online applications and Internet access, in particular, has begun to create a new paradigm of distribution of distance education programs from all around the world to the Arab world learners in new, flexible, and accessible ways. The interactive nature of the Internet has attracted distance students in the Arab world more than any other medium ever, and moved distance education away from correspondence mode to interactive and networking modes (Sadik, 2003). This strong demand was supported by research that compared educational outcomes of online and conventional programs. Many studies indicated that online distance education programs are equal to or better than conventional programs in terms of students' satisfaction, flexibility, and learning outcomes (Bernard et al., 2004; Machtmes \& Asher, 2000; Phipps \& Merisotis, 1999). 


\section{ACCEPTABILITY OF ONLINE DEGREES}

There is a common belief in the society that on-campus degrees are better than off-campus degrees for many reasons, such as residency in the university, real face-to-face experience, interaction among students, interactions between students and instructors, in addition to the accessible resources that could be in the learners' hands any time (Raj \& Al-Alawneh, 2010). Therefore, Arab employers, families, and students may feel reluctant to accept distance education as a formal alternative to conventional face-toface education. Therefore, many students may enroll in, and often withdraw from, distance education universities. Al-Harthi (2005) believes that students' cultural backgrounds and perceptions toward distance education degrees have a high effect on their willingness and ability to participate in distance education programs and their concerns can be traced back to the issue of acceptability of online degree as an employment credential. Research by Carnevale (2002) and Sikora (2003) has raised the question of whether the society regards online distance education degrees as valuable as degrees earned in a conventional way. Sikora indicated that those who hold online degrees are not judged as having qualifications that are equal to those of graduates who earn their degrees in a face-to-face program when seeking employment.

The concept of acceptability has been studied in very few online learning and distance education research studies. In those studies, respondents were asked to choose between candidates whose qualifications differed only in terms of learning mode, that is, whether they earned their credits online or in a traditional residential program. DeFleur and Adams (2004), for example, indicated that despite the rapid growth in online education, some educators and employers cast doubt on the quality of online courses and whether the learning experience and outcomes that take place over the Internet are equal to those occurring in traditional academic settings. Adams and DeFleur (2010), Adams and DeFleur (2006), and DeFleur and Adams (2004) found that there are some problems associated with the acceptability of online degrees when students apply to traditional postgraduate programs or faculty position in a traditional university. Adams, DeFleur and Heald (2007) also found that degrees earned online are "by no means as acceptable as traditional degrees, and that they can be regarded as suspect when used as a credential in a hiring situation" (p.43). They suggested that students should select their online universities with great care to increase their chances of being hired. In addition, Carnevale $(2005,2007)$ reviewed many empirical studies in the perceptions of employers toward online degrees and found that potential employers gave many reasons for not accepting online degree credentials. These reasons are: lack of rigor, lack of face-to-face interactions, academic dishonesty, reputation of the degree-granting institution, and appropriate level and type of accreditation.

\section{PROBLEM}

Today the concept of online distance education is well known and the importance of it towards the future of education, particularly in developing countries is wellacknowledged (Hertsch \& Şefika, 2016). With advances in multimedia and communication technologies, Despite extensive studies in online distance education, a few studies have been conducted to assess the acceptability of online distance education degrees by the society. While universities believe that the degrees they offer online are equal to traditional degrees, there appears to be a gap between the publics' perception of the online courses and the universities' belief in their online degrees. Oler (2006) indicated that the general attitude of the public in relation to online degrees is believed to be dismissive. In their seventh annual report on the state of online learning in U.S. higher education Allen and Seaman (2010) reported that while the number of online programs and courses continue to grow, the acceptance of this learning modality has been relatively constant since first measured in 2002 . In the Arab world, in particular, many students, job seekers, online universities, and distance education providers are unaware of the implications of earning online degrees and the lack of acceptance of online degrees within the society and as a credential for obtaining professional employment. At the same time, distance education institutions and instructional designers in the Arab world do not have adequate research-based information about the perceived value of online degrees in the Arab society, negative aspects of online learning, and factors that affect the societal acceptance of online programs and degrees.

\section{PURPOSE}

The main purpose of this study was to investigate the societal acceptance of degrees earned wholly online and defining the factors that positively or negatively affect the perceived value of these degrees in two Arab countries; Egypt and Oman. However, the study aimed to address the issue of acceptability of online degrees, not the merits of online distance education. This included defining factors and concerns, which are crucial to the design, and standards of online distance educational programs. By identifying these concerns and their importance, online distance education providers may be able to make use of this information in ways that can alleviate those objections and improve the acceptability of degrees earned online. An online distance education program is defined as the program in which students can obtain a degree totally online without the need to attend face-to-face classrooms.

\section{RESEARCH QUESTIONS}

The questions in the current research are intended to uncover information about the acceptability of university degrees earned online as equivalent to degrees earned in residential programs. Therefore, two research questions were raised for the purpose of this study.

1. How acceptable are online distance education degrees by the Arab society?

2. What are the factors affecting the acceptability of online distance education degrees that need to be considered by distance education institutions and developers?

\section{SignificAnce Of The StUdy}

The lack of literature on the topic, particularly in the Arab world, helps justify the significance of this study. This study contributes to the field of knowledge by helping online institutions benefit from understanding how societal acceptance affects students' employment opportunities and online institutions. By discovering the concerns raised by decision makers, stakeholders, employers, parents, and students, online course developers may be 
able to apply this information in ways that can alleviate those concerns. If that can be done, it may enhance the public perceived quality of online degrees earned by graduates to that of their traditional counterparts (Raj \& AlAlawneh, 2010). Therefore, this study was carried out to provide insight into "what counts" and to understand which instructional and organizational features affect the societal acceptance of online degrees in order to guide the future development of online distance education programs and help changing policies that lead to improvement of online teaching and learning conditions.

\section{METHOD}

As indicated above, the purpose of this study was to clarify the concerns that the Arab society has voiced with regard to online distance education degrees. By discovering these aspects of concern, online universities may be able to alleviate those objections and improve the quality of online programs.

\section{A. Instrument}

To answer the research questions, a societal acceptance of online distance education degrees questionnaire was developed by the author in several phases using both quantitative and qualitative methods. This multi-level approach was based on approaches suggested by Harrison et al., (1991) and Hogarty, Lang and Kromrey (2003) for developing similar instruments. The instrument development process occurred in four stages: delineation of relevant domains for the constructs of interest, survey assembly and pilot testing, large-scale field-testing, and validation of instrument scores using factor analytic and correlation methods.

\section{1) Credibility and Quality Domains}

The first step of instrument development involved a review of the distance education literature, including similar instruments, on various aspects of online distance education to conceptualize the domains that directly affect the acceptability of online degrees by the society. The review revealed many aspects, issues, and concerns that summarized why the public did not find online degrees as acceptable as traditional ones. These aspects are accessibility to learning resources, quality of content, use of appropriate communication technology, teaching and learning processes, learning experience, human interaction, evaluation techniques, academic integrity, rigor, and mentoring (DeFleur \& Adams, 2004; Carnevale, 2005; Adams \& Defleur, 2006; Carnevale, 2007; Guendoo, 2007; Adams, Defleur \& Heald, 2007; Adams \& DeFleur, 2010; Akbari, Naderi, Simons, \& Pilot, 2016). For the purpose of this study, these aspects were refined into two distinct domains that were most commonly mentioned as affecting the acceptability of online degrees; credibility and quality. The survey items were constructed based on the literature review and existing validated instruments related to these domains.

The first domain, credibility, refers to the extent to which online distance education degrees are credible or trustworthy in comparison with those earned in traditional ways. Credibility is the key to acceptability of online degrees. A key element of credibility involves transparency, trustworthiness, and moral predictability (Budzowski, 2012, Jehad, Gregg, \& Karimi, 2015). The areas of concern surrounding credibility of online degrees include rigor, mentoring, reputation of the university, accountability, assessment standards, and the challenges to the culture and traditions (Guendoo, 2007). Research indicated that reputation, for example, has a significant impact on the public's approval of a university degree (DeFleur \& Adams, 2004; Carnevale, 2005; Adams \& Defleur, 2006). Examples of statements that describe and measure the perceived credibility are "it is easy to apply for admission to an online program in my country compared to conventional education programs" and "It is too easy to cheat in an online program".

The second domain, quality, refers to the characteristics and standards of the distance education program a university offers. Quality of educational programs, in general, is usually associated with efficiency and effectiveness of the program. One way that distance educators have used to improve efficiency and effectiveness of online distance education programs is to establish and follow standards. Quality assurance is the set of activities that a university undertakes to ensure that standards are specified and reached consistently (Novak, 2002). The areas of concern surrounding quality of online degrees include the quality of content, quality of resources, qualifications of faculty, learners support, accreditation, nature learning experience, and the loss of face-to-face interaction (DeFleur \& Adams, 2004; Adams \& Defleur, 2006; Adams \& DeFleur, 2010). Examples of statements that used to measure perceived credibility are "the value of interaction in online programs can never be equated with that of face-to-face interaction in conventional settings" and "online programs can achieve the same outcomes as conventional ones if the courses are well-designed".

\section{2) Rating Scales}

The purpose of the second phase was to develop from the information in phase one a two-dimensional rating scale that could be used to assess the societal acceptance of online distance education and assess the content validity of its dimensions and their items as derived in phase one. Based on the conceptual definitions of the dimensions of assessment, each domain was examined for comprehensiveness and items were added or deleted to ensure appropriate and logical coverage. A panel, including distance education practitioners and educational technologists, of eight experts with adequate experience, was enlisted to review and reflect on these dimensions and items. Panel members were tasked with suggesting the addition or deletion of items and commenting on each item's importance within each domain based on their understanding of the conceptual definition of each domain.

The revised items were used to develop the rating scale of two sub-scales. Responses to credibility items were distributed over two five-point Likert scales. The first scale ranged from "Not at all concerned" to "Extremely concerned". The second scale ranged from "Strongly agree" to "Strongly disagree". The second domain, quality, also was distributed over the two five-point Likert scales mentioned above. Many items in each sub-scale were alternately presented or negatively worded to prevent clustering effects and also to prevent respondents from giving sets of positive or negative responses. In addition, a list of statements with checkboxes were added to allow participants indicate which aspects of online education they are most concerned about, such as evaluation techniques, academic integrity, rigor, and mentoring. Four open-ended questions regarding the credibility and quality 
PAPER

FACTORS AfFecting THE ACCEPTABILITY OF ONLINE DEGREES: EVIDENCE FROM TwO ARAB COUNTRIES

of online degrees were added at the end of the questionnaire. Examples of open-ended questions are "In your opinion, what is sacrificed when a course takes place online rather than in an on-campus classroom?" and "You have to make a choice between two graduates for a fulltime position at your school, university, hospital, company, etc. Both are equal in all respects, except that the first graduate holds an online degree while the second graduate holds a conventional degree in the same discipline. Which graduate will you select? Why".

The resulting dimensions and items were pilot tested with a sample of twenty-five participants from different educational and business backgrounds (faculty members, university students, teachers, medical doctors, school principals, training specialist, and business professionals) to assess the importance, clarity and wording of items. The items of the questionnaire were translated into Arabic by a language specialist and then back translated into English, by a different translator, to confirm the accuracy of the translation. Data based on the participants' responses and feedback aided revision of instrument content. The revised dimensions were assembled into one survey and included introduction about the study, purpose of survey, survey confidentiality statement, basic terms and definitions section, and demographic information (gender, age group, level of education, type of degree received, and job title).

\section{3) Field Testing}

The purpose of the third phase was to field test the questionnaire with a sample of the Arab society in Egypt and Oman. The questionnaire incorporating the checklist, rating scales, and open-ended questions generated from data in the second phase, included two versions one in Arabic and the other in English, was created and published online using Google Docs Forms. Compared to traditional survey methods, online surveys are more efficient and cost effective, and provide automated data collection and instant responses (Verma and Jin, 2005). Couper (2000) suggested two approaches of online surveys; probability-based sampling and non-probabilitybased (convenience) sampling. Non-probability samples refer to samples where the sampling frame is not welldefined and there is no known probability of selection. Since contacting respondents via traditional media (e.g., phone, post mail, etc.) introduces other complications and costs, invitations always made via e-mail, and, because email lists of general populations are simply not available, probability-based sampling approach (e.g., list-based or non-list-based sampling frame) is not applicable to large homogeneous groups for which a sampling frame with email addresses cannot be assembled. For non-probabilitybased methods (e.g., harvested e-mail lists), either a convenience sample is drawn, from which the probabilities that various members of the population being included in the sample cannot be determined, or the survey is distributed or advertised in some manner and it is left up to those exposed to the survey to choose to participate.

However, since drawing an appropriate sample that would be able to answer questions related to the credibility and quality of online distance education is critical, the most common example of non-probability based methods, called "harvested e-mail lists", was employed. Harvested e-mail lists are collected by some means from the web, either automatically or manually for e-mail addresses that are posted on websites. Samples derived from harvested e- mail lists are non-probability samples because they are based on a convenience sample of e-mail addresses, which are often an aggregation of data collected from websites of organizations (e.g., universities, government organizations, large corporations, etc.), public mailing lists, or social networks. However, Fricker (2008) proposes that these types of non-probability samples can be useful and appropriate for collecting data from the public. In addition, since there is no systematic way to sample the general population using the internet and there is no national list of e-mail addresses from which people could be sampled, as there is for phone numbers that would allow random sampling, harvested e-mail lists method was employed in this study.

The researcher collected more than 1200 email addresses from websites of universities, schools, government organizations, companies, and large corporations in Egypt and Oman. A message was sent to each individual asking for permission to send more information about the survey and the survey link. Participation was voluntary and the confidentiality of individual responses was guaranteed. Response rates were monitored over a three-week period. After two follow-up email messages, responses were received from 732 respondents from manufacturing, health care, education, financial services, government administration, information technology, and other sectors agreed to participate and respond to the questionnaire (a $61 \%$ response rate). Care was taken to identify differences between respondents to the survey and the general population of the society. Comparisons of gender, age group, education, and sector revealed no significant differences between respondents and non-respondents, suggesting that non-response bias was not a concern for this study.

\section{4) Psychometric Characteristics of the Instrument}

In the last phase, the psychometric characteristics of the instrument were investigated using exploratory factor analyses and Cronbach's alpha. Since the instrument was divided into logically and practically two sub-scales, common factor analysis was applied within the scale to verify whether the scale only measured one dimension. Factors were extracted based on the proportion of variance explained by each factor. To perform exploratory factor analysis, only 30 percent (220) of the sample were provided with a link to the questionnaire website and asked to respond to the questionnaire items. After list-wise deletion of missing data, responses were available for 2 respondents. Principle component analysis with varimax rotation on the 39 items identified two interpretable factors: "credibility" and "quality". Items loaded greater than \pm 0.40 were retained on the relevant factor and items loaded less than \pm 0.40 were omitted. Thus, item analysis reduced the original 39 items to 33 items with two independent constructs. The results show that factor loadings range between 0.42 and 0.78 on the "credibility sub-scale. This factor was defined by 14 items that represented credibility, authenticity, legitimacy, accessibility, cheating, and so on. Factor loadings range between 0.45 and 0.86 in the 'quality' domain. This factor was defined by 19 items concerning quality of content, interaction, qualifications of faculty, and so on.

This behavior of individual items in relation to others within the same sub-scale provides good evidence of content validity, since the highest factor loadings are central to the domains assessed by these sub-scales (Francis, Katz and Jones, 2000). A Cronbach's coefficient was calculated 
for the two sub-scales ( 0.79 and 0.81 respectively) and the entire scale $(0.87)$. The item rest of scale correlation coefficients range between 0.42 and 0.81 on credibility subscale, and between 0.69 and 0.82 on quality sub-scale. It is generally agreed that these values of correlations are useful and statistically significant beyond the one- percent level, suggesting that the internal reliability index of the two constructs and the entire scale were adequate. The results of inter-correlations show that, overall, each subscale (credibility and quality) correlates significantly with the other sub-scale and the entire scale. According to Harrison et al. (1991), this result provides further evidence for the consistency of the entire questionnaire and for the convergent validity of each sub-scale. Therefore, it can be concluded that the two sub-scales measure the acceptability of online degrees in a coherent way. The revised questionnaire was re-administrated to the remaining 70 percent (512) of the sample. After two follow-ups of nonrespondents by email, responses were received from 479 participants from Egypt and Oman.

\section{B. Sample}

After two follow-ups of non-respondents by email, responses were received from 479 participants from Egypt and Oman. Of the 479 participants in this study, 34 percent were Omani and 66 percent were Egyptians. This disparity in the level of participation was due to large population of Egypt (82 million) compared to Oman (2.7 million). Around 79.5 percent were male and 20.5 percent were female. However, this steep disproportion between male and female respondents does not reflect disproportion between male and female in the Arab society.

\section{RESUlTS}

In terms of age, the majority of participants $(75 \%)$ were between the ages of 22 and 54 years. Only 13 percent were under age 21. More than 58 percent of those who responded to the questionnaire have a bachelor degree, and 24 percent have a master's or/and doctoral degree. Nearly all participants $(98 \%)$ received their degree via conventional education. They are distributes as follows: from education institutions $(23 \%)$, government and public administration $(11 \%)$, public or private associations $(11 \%)$, professional sector $(9 \%)$, and information technology $(6 \%)$. Lastly, 66 percent of participants indicated that they were not aware if their organizations hired applicants with online degree or not. Only 4 percent of participants confirmed that their or organization or work place had employed candidates with online degrees (Table I).

The results are organized to address the research questions.

Question 1: How acceptable are online distance education degrees by the society?

Although there is no doubt that online distance education programs offer are convenient to thousands of Omani and Egyptian students and job seekers who are unable to attend conventional classrooms to continue their studies, the findings suggest strongly that, overall degrees earned via online distance education programs are by no means as acceptable as traditional degrees, and that a degree earned online is in many ways not similar to those earned in traditional education settings $(79.39 \%)$. In terms of credibility of online degrees, although the majority of respondents strongly agreed or agreed that online distance education
TABLE I.

DEMOGRAPHIC PROFILE OF RESPONDENTS

\begin{tabular}{|c|c|}
\hline \multicolumn{2}{|l|}{ Demographic information } \\
\hline \multicolumn{2}{|l|}{ Gender } \\
\hline Male & $79.5 \%$ \\
\hline Female & $20.5 \%$ \\
\hline \multicolumn{2}{|l|}{ Age group } \\
\hline 21 and below & $13 \%$ \\
\hline 22 to 34 & $20 \%$ \\
\hline 35 to 44 & $31 \%$ \\
\hline 45 to 54 & $24 \%$ \\
\hline 55 to 64 & $12 \%$ \\
\hline 65 and Over & $0 \%$ \\
\hline \multicolumn{2}{|l|}{ Education } \\
\hline Enrolled university student & $10.5 \%$ \\
\hline Bachelor & $58.5 \%$ \\
\hline Master & $9 \%$ \\
\hline Doctorate & $15 \%$ \\
\hline Other & $7 \%$ \\
\hline \multicolumn{2}{|l|}{ Source of degree received } \\
\hline Face-to-face & $98 \%$ \\
\hline Online & $2 \%$ \\
\hline \multicolumn{2}{|l|}{ Organization/business sector } \\
\hline Manufacturing & $3 \%$ \\
\hline Health care, social assistance & $6 \%$ \\
\hline Professional & $9 \%$ \\
\hline Scientific & $7 \%$ \\
\hline Education & $23 \%$ \\
\hline Financial Services & $5 \%$ \\
\hline Government/public administration & $11 \%$ \\
\hline Construction, mining, oil and gas & $2 \%$ \\
\hline High-Tech & $6 \%$ \\
\hline Arts, entertainment, recreation & $2 \%$ \\
\hline Telecommunications & $5 \%$ \\
\hline $\begin{array}{l}\text { Publishing, broadcasting, and other } \\
\text { media }\end{array}$ & $3 \%$ \\
\hline Association & $11 \%$ \\
\hline Medical/Pharmaceutical & $3 \%$ \\
\hline Other & $4 \%$ \\
\hline \multicolumn{2}{|l|}{ Employment of online applicant } \\
\hline Yes & $4 \%$ \\
\hline No & $30 \%$ \\
\hline Do not know & $66 \%$ \\
\hline
\end{tabular}

can solve a lot of our educational problems $(62.50 \%)$ and increase access to education and training in the Arab world $(71.25 \%)$, the majority of respondents also strongly agreed or agreed that in the case of online programs, it is much easier to apply for admission (83.13\%), cheat $(62.50 \%)$, and scarify many aspects of residential education $(90.24 \%)$. Moreover, online programs are more revenue-driven than intellectually driven $(93.75 \%)$, not rigorous enough to ensure mastery of a subject area $(83.75 \%)$, and not legitimate as traditional degrees $(81.25 \%)$. Only $64.38 \%$ of respondents indicated that they have no problem with an online program once it comes from an institution with a reputable conventional program. Lastly, when respondents were asked about hiring online graduates, 91.13 percent strongly agreed or agreed that they prefer to hire a graduate with a conventional degree over one with 
an online degree in a position in their organization, university school, or company. Table II shows that respondents generally had low level of acceptance of credibility of online degrees.

Regarding the quality of online programs, respondents $(71 \%)$ believe that low quality of instruction is a major weakness of online programs in the Arab world (Table III). They are confident that online degrees are lower in quality $(80.25 \%)$, and not capable of helping students to achieve the same outcomes as conventional ones, even if the courses are well-designed $(64.80 \%)$. In terms of the quality of interaction, the findings revealed that interaction in online programs can never be equated with the value of face-to-face interaction in conventional settings. They strongly agreed or agreed that online programs are neither capable of establish a sense of academic community (73\%) nor develop the verbal and communication skills of the candidates like conventional programs (91.10\%). Overall, the results show that online programs are believed to be not effective for student learning in the Arab world, due to the low quality of teaching and learning standards. The examination of mean differences of the credibility and quality sub-scales showed that there is no significant differences between respondents scores in the two sub-scales.

Results were further broken down by age, education level, and business sector. Plotting the results on a graph, it showed that they best fit a linear relationship. The ANOVA tests were used to analyze the differences among some groups of participants and their acceptance of online degrees. Overall, responses indicated that there is no significant differences among participants. One-way ANOVA and Scheffe tests (at .05 level) were used to identify whether there were significant differences in the acceptability of online degrees between respondents from different age groups, with different education levels, and whether they were students or employees at different business sectors. The results showed no significant difference in the acceptance of online degrees $(\mathrm{F}=0.08, \mathrm{p}=0.99)$ among respondents from different age groups. In similar manner, no significant differences existed $(\mathrm{F}=1.11$, $\mathrm{p}=0.35$ ) among the participants from the different five education levels (enrolled university student, bachelor, master's, doctorate, and other sectors). Lastly, although no significant differences in the overall score were found among respondents from the different major business sectors, one-way ANOVA and Scheffe tests (at .05 level) showed that no significant differences existed $(\mathrm{F}=1.11$, $\mathrm{p}=0.35$ ) between the major groups business sectors (e.g., manufacturing, health care, scientific, education, government and public administration, etc.). However, through a series of Scheffe test (Post Hoc tests), it can be concluded that government/public administration sector respondents are more likely willing to accept the quality of online degrees than respondents from the medical/pharmaceutical sectors.

Question 2: What are the factors affecting the acceptability of online distance education degrees that need to be considered by distance education institutions and developers?

\section{A. Quantitative findings}

To define factors or concerns affecting the credibility and quality of online degrees as perceived by respondents, respondents were asked to rank 12 issues that may affect
TABLE II.

THE CREDIBILITY OF ONLINE DEGREES

\begin{tabular}{|l|c|c|c|}
\hline \multicolumn{1}{|c|}{ Sub-scale } & $\begin{array}{c}\text { SA \& } \\
\text { A \% }\end{array}$ & Mean & $\begin{array}{l}\text { Std. } \\
\text { Dev. }\end{array}$ \\
\hline $\begin{array}{l}\text { 1. Online distance education can solve a lot } \\
\text { of our educational problems in the Arab } \\
\text { world. }\end{array}$ & 62.50 & 3.63 & 1.0701 \\
\hline $\begin{array}{l}\text { 2. Online distance education increases access } \\
\text { to education and training in the Arab world. }\end{array}$ & 71.25 & 3.60 & 1.0160 \\
\hline $\begin{array}{l}\text { 3. It is easy to apply for admission to an } \\
\text { online program in Arab country, compared to } \\
\text { conventional education programs in the same } \\
\text { region. }\end{array}$ & 83.13 & 4.11 & 1.1876 \\
\hline $\begin{array}{l}\text { 4. Online degrees in the Arab world are more } \\
\text { revenue-driven than intellectually driven. }\end{array}$ & 93.75 & 4.40 & 0.6148 \\
\hline $\begin{array}{l}\text { 5. Online courses are not rigorous enough to } \\
\text { ensure mastery of a subject area. }\end{array}$ & 83.75 & 4.03 & 1.3072 \\
\hline $\begin{array}{l}\text { 6. I have no issues with an online program } \\
\text { once it comes from an institution with a } \\
\text { reputable conventional program. }\end{array}$ & 64.38 & 3.01 & 0.9755 \\
\hline $\begin{array}{l}\text { 7. It is way too easy to cheat in an online } \\
\text { program. }\end{array}$ & 62.50 & 3.63 & 1.0701 \\
\hline $\begin{array}{l}\text { 8. With or without a face-to-face component, } \\
\text { online programs are not legitimate. }\end{array}$ & 81.25 & 4.00 & 1.0160 \\
\hline $\begin{array}{l}\text { 9. I would normally prefer to hire a graduate } \\
\text { with a conventional degree over one with an } \\
\text { online degree for a position in my company. }\end{array}$ & 91.13 & 4.41 & 1.1876 \\
\hline $\begin{array}{l}\text { 10. Many aspects of education are sacrificed } \\
\text { in online programs compared to conventional } \\
\text { way. }\end{array}$ & 90.24 & 4.63 & 1.0701 \\
\hline Overall score & 79.39 & 3.99 & 1.0457 \\
\hline
\end{tabular}

TABLE III

THE QUALITY OF ONLINE DEGREES

\begin{tabular}{|l|c|c|c|}
\hline \multicolumn{1}{|c|}{ Sub-scale } & $\begin{array}{l}\text { SA \& } \\
\text { A \% }\end{array}$ & Mean & $\begin{array}{c}\text { Std. } \\
\text { Dev. }\end{array}$ \\
\hline $\begin{array}{l}\text { 11. Online education in the Arab world is } \\
\text { lower in quality than traditional, face-to-face } \\
\text { education. }\end{array}$ & 80.25 & 4.24 & 1.0396 \\
\hline $\begin{array}{l}\text { 12. Online programs can achieve the same } \\
\text { outcomes as conventional ones if the courses } \\
\text { are well-designed. }\end{array}$ & 64.80 & 3.53 & 1.1813 \\
\hline $\begin{array}{l}\text { 13. Online programs fail to establish a sense } \\
\text { of academic community. }\end{array}$ & 73.00 & 3.73 & 1.0757 \\
\hline $\begin{array}{l}\text { 14. The value of interaction in online pro- } \\
\text { grams can never be equaled with value of } \\
\text { face-to-face interaction in conventional } \\
\text { settings. }\end{array}$ & 67.75 & 3.28 & 1.0733 \\
\hline $\begin{array}{l}\text { 15. Unlike conventional programs, the time } \\
\text { spent in the laboratory learning new tech- } \\
\text { niques in certain courses are significantly } \\
\text { curtailed with online delivery. }\end{array}$ & 69.80 & 3.86 & 1.0836 \\
\hline $\begin{array}{l}\text { 16. Accredited online programs are able to } \\
\text { meet all the standards of the conventional } \\
\text { programs. }\end{array}$ & 73.70 & 3.93 & 1.0096 \\
\hline $\begin{array}{l}\text { 17. An online graduate is less prepared for } \\
\text { working (as a teacher, doctor, engineer, etc.) } \\
\text { than a conventional graduate. }\end{array}$ & 74.20 & 3.76 & 1.1662 \\
\hline $\begin{array}{l}\text { 18. Online programs do not develop the } \\
\text { verbal and communication skills of the } \\
\text { candidates as conventional programs. }\end{array}$ & 91.10 & 4.74 & 0.5487 \\
\hline $\begin{array}{l}\text { 19. Low quality of instruction is a major } \\
\text { weakness of online programs in the Arab } \\
\text { world. }\end{array}$ & 67.80 & 3.83 & 1.1813 \\
\hline $\begin{array}{l}\text { 20. Online programs increase the quality of } \\
\text { teaching and learning if they integrate all } \\
\text { forms of media and technology. }\end{array}$ & 46.90 & 3.32 & 1.2353 \\
\hline $\begin{array}{l}\text { 21. Overall, online programs in the Arab } \\
\text { world are not effective for student learning. }\end{array}$ & 72.80 & 3.56 & 1.0836 \\
\hline Overall score & 71.10 & 3.79 & 1.1735 \\
\hline
\end{tabular}


the acceptability of online distance education degrees using a five-point Likert scale from "Extremely concerned" to "Not at all concerned". The issues were ranked and listed in order by the mean rank of concern in Table IV. The findings indicated serious concerns regarding many aspects of online learning degrees amongst the respondents and showed that the majority of respondents $(90 \%)$ were extremely or moderately concerned about the reality of interaction between students and the instructor, as a key issue of online distance education programs. The findings also suggest that the perception of face-to-face contact with instructors and mentoring should be considered to be an important key factor to what many of those who would consider a quality online education. This issue was followed by concerns regarding the credibility of online degrees with employers $(89.12 \%)$, interactions among students themselves (89.02\%), and online support by instructors $(89.07 \%)$. The findings also showed that respondents were not at all concerned or slightly concerned about many issues in online programs, such as qualifications of online instructors $(89.05 \%)$, academic collaboration among online learners $(87.66 \%)$, and motivation of students to learn online $(85.77 \%)$.

\section{B. Qualitative findings}

To learn more about the factors affecting the acceptability of online degrees and to validate the quantitative findings above, respondents' opinions were collected using the last section of four open-ended questions of the questionnaire. The responses to the questions are organized, analyzed, and coded to address the pattern of responses. The first open-ended question evoked responses to make a choice between two candidates for hiring in a full-time position. Both candidates are equal in all respects, except that the first one holds an online degree while the second holds a conventional degree in the same discipline and to provide a reason or justification for this choice. The second question asked respondents to define the features of traditional education, which they believe that they were sacrificed when a course is offered online and affect the quality of program outputs. The third and fourth questions concerned the advantages and limitations of receiving a degree via online distance education compared to conventional degrees. Comments received from 32 respondents (6.7\% of the total number of participants). A content analysis of comments was conducted to identify with the nature of those choices in context, and to examine comments for evidence of overriding concerns. To accomplish this analysis, the written comments were first organized into categories (general aspects, credibility aspects, quality issues, issues sacrificed, advantages, and limitations) and analyzed into patterns of feedback, then translated into English for the purpose of this article, as shown in Table IV.

Generally, the responses and comments supported the quantitative findings. Respondents indicated clearly that traditional degrees are more acceptable, and that a degree earned online was of limited value for job applicants. In addition, they commented that, if they were in a position to hire, they would prefer to hire an applicant with a traditional degree rather an applicant with an online degree. They provided general different reasons that supported their choices. For example, the effectiveness of online teaching, online support, and academic collaboration, and issues related to the cultural acceptance of online degrees.
TABLE IV.

CONCERNS ABOUT ASPECTS THAT AFFECT THE CREDIBILITY AND QUALITY ONLINE DEGREES

\begin{tabular}{|l|c|c|c|}
\hline \multicolumn{1}{|c|}{ Factors } & $\begin{array}{c}\text { Ext. \& } \\
\text { Mod. } \\
\text { Conc. \% }\end{array}$ & Mean & $\begin{array}{c}\text { Std. } \\
\text { Dev. }\end{array}$ \\
\hline $\begin{array}{l}\text { 1. Interaction between students and the } \\
\text { instructor }\end{array}$ & 90.02 & 4.21 & 0.5150 \\
\hline 2. Credibility with employers & 89.12 & 4.05 & 0.5304 \\
\hline 3. Interaction among students themselves & 89.08 & 4.07 & 0.5304 \\
\hline 4. Instructor support & 89.07 & 4.17 & 0.5304 \\
\hline 5. Qualifications of instructors & 89.05 & 4.31 & 0.5150 \\
\hline 6. Academic collaboration among learners & 87.66 & 4.21 & 0.5150 \\
\hline 7. Motivation of students to learn & 85.77 & 4.08 & 0.5304 \\
\hline 8. Authenticity of students' work & 88.25 & 4.11 & 0.4232 \\
\hline 9. Admission regulations & 81.03 & 3.51 & 0.4232 \\
\hline 10. Quality of course content and materials & 77.19 & 3.82 & 0.515 \\
\hline 11. Quality of learning outcomes & 77.10 & 3.42 & 0.4232 \\
\hline $\begin{array}{l}\text { 12. Preparation for working in convention- } \\
\text { al settings }\end{array}$ & 76.05 & 3.55 & 0.4232 \\
\hline Overall Mean & 85.32 & 3.96 & 0.5234 \\
\hline
\end{tabular}

The most frequent pattern of concerns was the quality online interaction between the student and the instructor, which was highlighted by nine respondents. This pattern surfaced as the most troubling aspect of online programs. The comments that addressed concerns on online interaction were longer, and more passionate. Such comments mentioned online interaction and experience as a reason for not accepting online degrees.

For example, a respondent addressed that "I know that online degrees are becoming more acceptable today but interaction with professors and classmates is an essential part of education and that this experience can only be gained by attending traditional classes". Other two respondents added that "There is no substitute for face-toface interaction between the professors and students in the classrooms. This kind of dialogue and experience is essential for future student success and online programs do not provide this kind of experience", and "The academic life requires interaction between students and professors and the Internet cannot compensate this experience". A third respondent said that "I can accept an online degree in history, literature, or math but not in fields such as education, medicine or engineering that require face-to-face interaction, real experience and lab attendance". Lastly, a respondent referred to the culture and traditions in the Arab world, which look at attending residential face-toface classes as the only way to education. He commented that "One of the factors that affects the acceptance of online graduates in our Arab society is the attitude toward online universities. People respect and fond of students who are enrolled in traditional universities, and attend lectures".

Acceptability issues were further broken down by credibility and quality. In terms of credibility, the respondents indicated that regulations of admission in online learning programs, authenticity of students' assignments and course work, and the problem of dishonesty are the most important issues that affect credibility of online degrees. A respondent indicated that "Acceptability of an online degree depends on the reputation of the university conferring the degree. I cannot accept a degree from any online uni- 
versity and many of them sell fake degrees nowadays". In addition, another respondent reported "I do not trust the work performed by online students in this kind of online studies. Fraud and counterfeit are very easy and even perhaps any one can do the work on behalf of the student".

In terms of quality, respondents reported that quality of online teaching practices, learning resources, which the students can access, textbooks, and interaction between the students and the instructor are the major issues affecting acceptability of online degrees. A number of respondents believe that interaction with peers and teachers is an integral part of learning and the reality of this interaction affects the quality of online programs. A respondent said that "Online students lose the experience of team working and the ability to learn from each other. This experience is useful in many work environments and employers prefer graduates who have them". In terms of the quality of course content, a respondent wondered whether the quality of online programs is the same as traditional programs: "The level and quality of teaching in these universities is unclear and unknown to many of us. Is their level of teaching and courses the same as that of traditional universities?"

Regarding the issues that are sacrificed in an online program rather than in an on-campus program, respondents expressed concern over the academic integrity in online programs, academic rigor or the standards and expectations of online learners, academic relationships between the students and the instructor and among students, and student facilitation. Examples of statements by respondents in response to what is sacrificed: "This type of education has many sacrifices in many sides at the expense of the educational aspects such as criteria of admission, academic level of students, academic rigor, and evaluation of student coursework. The evidence is that most students who are admitted in these online universities are not accepted in conventional universities or are not able to compete with others in these universities". Another respondent believes that the human factor has been sacrificed in online program. He commented that "A great deal is sacrificed by studying online. One of the most important factors that is sacrificed in online distance education programs is the social relationships, which cannot be compensated or replaced by any interaction via modern technology".

Lastly, although respondents believe that online programs provide new methods of assessment, improve students' computer and internet skills, and help students to be life-long learners, they raised many disadvantages of online degrees, such as cheating on online exams and assignments, limited access to the instructor, lack of direct communication and exchange of knowledge with other students, and lack of hands-on or practical work. As noted in Table $\mathrm{V}$, cheating on exams or coursework as well as inability of verifying the identity of online students in exams were mentioned most frequently and are regarded as an indication that this issue is very important for respondents when they compare online degrees with traditional degrees. Respondents believe that online studies lend themselves more easily to cheating due to the lack of face-to-face monitoring between the students and instructor. In terms of advantages, a respondent commented that "Online programs use modern technology and improve students' technical skills, provide a lot of information
TABLE V.

ANALYSIS OF OPEN-ENDED RESPONSES

\section{Category/Pattern (frequency)}

\section{Which graduate will you select? Why?}

1.2. Credibility aspects

1.2.1.Authenticity of students' work (4)

1.2.2.Admission regulations (7)

1.2.3. The problem of dishonesty (3)

1.3. Quality aspects

1.3. 1.Quality of support (6)

1.3. 2. Quality of Interaction between students and the instructor (5)

1.3. 3. Interaction among students (4)

1.3. 4. Quality of course content (5)

1.3. 5.Quality of resources (6)

1.3. 6. Quality of teaching(7)

2. What do you think is sacrificed when a course takes place online rather than in an on-campus classroom?

2. 1.Direct teaching and learning experience (4)

2. 2.Human interaction (4)

2. 3.Face to face assessment (5)

2. 4.Academic integrity (8)

2. 5.Academic rigor (7)

2. 6.Mentoring (3)

3.7. Student support (5)

3. What advantages do you think online programs have over conventional programs?

3.1. New methods of assessment (1)

3.2. Improving students' IT skills (4)

3.3. Life-long learning skills (1)

\section{What disadvantages do you think online programs have com-} pared to conventional programs?

4.1. Cheating on exams (7)

4.2. Relationships with instructors $(6)$

4.3. Difficulty getting hired (5)

4.4. Stigma associated with online degrees (4)

4.5. Verifying the identity of online students (6)

4.6. lack of real interaction (5)

sources, provide assistance for each individual student, and make students in continuous activity". Considering another point of view, some respondents mentioned many of the above issues as limitations of online programs. A respondent said that "My perception is that online degrees are not as rigorous as traditional degrees, and this is why online degree holders do not have equal employment opportunities. Most employers whether in the public sector or the private sector do not recognize or grant these degrees. Online learning universities can become better if they are a mix of traditional universities and fully online universities".

\section{Discussion AND IMPLICATIONS}

There is no question that online distance education programs offer a convenient means for millions of degreeseeking students in the Arab world who are otherwise unable to attend classes in a face-to-face setting. However, while the spread of online learning universities is growing, the society still believes that the quality of an online education degree is not the same as one gained in a physical building. While online distance education providers believe that the quality of online learning is equal to or even superior to face-to-face instruction (Allen \& Seaman, 2010), the findings of this study indicate that the overall perception expressed by respondents was that online distance education was viewed as inferior to traditional education and a degree earned online is not similar to one earned in traditional settings in terms of credibility and quality. The acceptability of online degrees has been criti- 
cized from many perspectives, one being whether or not online distance education programs are as effective as traditional face-to-face programs. Respondents did not believe that online distance education offer an equal value compared with face-to-face education.

The majority of public criticized the credibility and quality of online distance education programs in the Arab world because they believe that online universities could lead to dishonesty and cheating in coursework and exams, ignore admission standards and regulations, and do not pay much attention to practical skills, sense of academic community, and direct interaction. In addition, the respondents did not support the idea of getting a degree online because they did not believe that online distance education actually can achieve the same quality of outcomes as conventional ones. The results also indicate that the public were very concerned about many traditional educational issues that affect acceptability of online learning degrees in the Arab world. These concerns include the reality and types of interaction between students and instructor and among students themselves, regulations of admissions in online universities, reputation of a university, and credibility with employers in the public and private sector.

The results of this study seem to agree with those found outside the Arab world. Parker, Lenhar, \& Moore (2011) indicated that only $29 \%$ of the wider public in the United States view online education as carrying the same value as an on-campus program. These findings emphasize the need for further development of online programs to improve the overall societal acceptance of many issues, such as student-instructor relationship, evaluation of student academic progress. This development may require using new communication strategies and technologies to facilitate interaction between students and the teacher and ensure the quality of learning outcomes. In addition, online distance education developers need to define specializations or fields of study that online distance education may, or may not, be suitable for, such as studies that require high degrees of interaction, mentoring, coaching, direct experience, or hands-on practical lab.

In addition, online distance education providers and practitioners in the Arab countries may need to adopt open or blended learning approaches rather than fully online learning approach to overcome concerns and avoid criticism by the public, offer the best of conventional environment and online settings, provide different ways to open access to non-traditional learning opportunities to a diverse range of students, and convince the society and employers. Blended learning approach implies presenting online instruction with a blend of the traditional face-toface approach and incorporating a variety of delivery techniques, specifically group and individual studies, resource based learning, service learning, and cooperative learning that involve both online and in-person activities. In addition, since there is a shared perception among the public that it is easier to cheat in an online university than in an on-campus class, blended learning strategies may help in monitoring and identifying the identity of students in exams and coursework submission. Finally, further research is needed to investigate whether blended or open learning approaches meet the expectations of the society and change the negative view and misconceptions of the value of fully online degrees and reputation of online universities.

\section{CONCLUSION}

Although many studies have been conducted within the last ten years to examine the effectiveness of online programs compared to traditional education, little attention has been paid to the acceptance of online degrees by the society and what happens to graduates when seeking to make use of their degrees. This study confirms the public belief that traditional degrees are still more preferable than online degrees in the Arab world for many reasons, such as the reality of online interaction between students and the instructor and among students, accessibility resources, credibility of online universities, and quality of content, which are important keys to what the public would consider a quality education. If online distance education universities can dispel these fears and concerns, it may raise the perceived quality of online degrees by the society. A new world of online distance education demands new ways for learning and thinking and a considerable attention to the psychological aspects of learning. How the process is designed, delivered, integrated, and supported are key components to improve the quality and acceptance of online distance education systems (Hrtoňová, Kohout, Rohlíková, \& Zounek , 2015; Schornack, \& Beck, 2016).

Continued research in this area may provide insights for enhancing online student-instructor relationship, expanding accessibility to quality resources, and improving the quality of teaching and learning online. In addition, further research is needed to investigate the factors affecting the acceptability of online degrees from the perspective of potential employers in the Arab world.

\section{REFERENCES}

[1] Adams, J. Teaching Certificates Earned Online and Hiring Practices of High School Principals. Journal of Educational Issues, vol. 2, no. 1, pp. 73-90, 2016. https://doi.org/10.5296/jei.v2i1.8203

[2] Akbari, E., Naderi, A., Simons, A. \& Pilot, A. Student engagement and foreign language learning through online social networks. Asian-Pacific Journal of Second and Foreign Language Education vol. 1, no. 4, 2016, Available online at https://sfleducation.springeropen.com/articles/10.1186/s40862016-0006-7

[3] Adams, J. \& DeFleur, M. The Acceptability of a Doctoral Degree Earned Online as a Credential for Obtaining a Faculty Position, American Journal of Distance Education, vol. 19, no. 2, pp. 71-85, 2010https://doi.org/10.1207/s15389286ajde1902 2

[4] Adams, J., Defleur, H. \& Heald, R. The acceptability of credentials earned online for obtaining employment in the health care professions. Communication Education, vol. 56, no. 3, pp. 292307, 2007. https://doi.org/10.1080/03634520701344959

[5] Adams, J., \& DeFleur, M. The acceptability of online degrees as a credential for obtaining professional employment. Communication Education. vol. 55, no. 1, pp. 32-45, 2006. https://doi.org/10.1080/ 03634520500343376

[6] Al-Harthi, A. Distance Higher Education Experiences of Arab Gulf Students in the United States: A cultural perspective. The International Review of Research in Open and Distance Learning. vol. 6 , no. 3, 2005. Available online at http://www.irrodl.org/in dex.php/irrodl/article/view/263/406.

[7] Allen, I. \& Seaman, J. Learning on Demand: Online Education in the United States 2009. United States: Babson Survey Research Group, 2010.

[8] Allen, I., \& Seaman, J. Entering the mainstream: The quality and extent of online education in the United States, 2003 and 2004. Wellesley, MA: Sloan Consortium.

[9] Arab Gulf Program for United Nations Development Organizations. Arab Open University, 1999. Available online at www.agfund.org/ebody_aou.html 
[10] Bernard, M., Abrami, C., Lou, Y., Borokhovski, E., Wade, A., Wozney, L., Wallet, A., Fiset, M., \& Huang, B. How does distance education compare to classroom instruction? A Metaanalysis of the empirical literature. Review of Educational Research, vol. 74, no. 3, pp. 379-439, 2004. https://doi.org/10.3102/ 00346543074003379

[11] Budzowski, B. Five Keys to Credibility at Work. inCredible Messages, Pittsburgh, PA 15206, 2012. Available at http://www.incrediblemessages.com/Articles/cc-15-five-keys.htm

[12] Carnevale, D. Colleges demand that Fakedegrees.com remove their names from its web site, 2002. The Chronicle of Higher Education, 49, A44

[13] Carnevale, D. Employers still prefer traditional degrees over online learning, study finds. The Chronicle of Higher Education, vol. 52, no. 5) A43, 2005.

[14] Carnevale, D. Employers often distrust online degrees: Some say they prefer job applicants who earned diplomas the old-fashioned way. The Chronicle of Higher Education, vol. 53, no. 18, A28, 2007

[15] Couper, P. Review: Web Surveys: A Review of Issues and Approaches. The Public Opinion Quarterly, vol. 64, no. 4: pp. 464494, 2000. https://doi.org/10.1086/318641

[16] DeFleur, M., \& Adams, J. Acceptability of online bachelor's degrees as criteria for admission to graduate programs. Journal of Computing in Higher Education, vol. 16, no. 1, pp. 150-161, 2004. https://doi.org/10.1007/BF02960287

[17] Francis, L., Katz, Y. \& Jones, S. The reliability and validity of the Hebrew version of the Computer Attitude Scale. Computers \& Education. vol. 35, no. 2, pp. 149-59, 2000. https://doi.org/10.1016/S0360-1315(00)00022-1

[18] Fricker, D. Sampling methods for web and e-mail surveys. In Fielding, M. \& Blank, G. (Eds.), The SAGE handbook of Online Research Methods (pp. 195-216). London. SAGE. Publications, 2008. https://doi.org/10.4135/9780857020055.n11

[19] Guendoo, L. Credibility challenges to online doctoral graduates seeking faculty positions: A community college perspective. Unpublished doctoral dissertation, Capella University, USA, 2007.

[20] Harrison, P.J., Seeman, B.J., Behm, R., Saba, F., Molise, G., \& Williams, D. Development of a distance education assessment instrument. Educational Technology Research \& Development, vol. 39, no. 4, pp. 65-77, 1991. https://doi.org/10.1007/BF02296572

[21] Hertsch, F. \& Şefika, E. Barriers and Challenges of Distance Learning in Turkey and the Demand for Distance Education Centres (UEM). In Chaos, Complexity and Leadership, pp. 271-277, 2014.

[22] Hogarty, Y., Lang, R., \& Kromrey, D. Another look at technology use in classrooms: The development and validation of an instrument to measure teachers' perceptions. Educational and Psychological Measurement, vol. 63, no.1 , pp. 139-162, 2003. https://doi.org/10.1177/0013164402239322

[23] Hrtoňová, N., Kohout, J., Rohlíková,, L.\& Zounek, J. Factors influencing acceptance of e-learning by teachers in the Czech Republic. Computers in Human Behavior, vol. 51, no 1, pp. 873-879.

[24] Jehad, I, Gregg, D. \& Karimi, J. Student engagement in coursebased social networks: The impact of instructor credibility and use of communication. Computers \& Education, vol 88. pp. 84-96, 2015. https://doi.org/10.1016/j.compedu.2015.04.015

[25] Machtmes, K. \& Asher, W. A Meta-analysis of the Effectiveness of Telecourses in Distance Education. The American Journal of
Distance Education, vol. 11, no. 1, pp. 29-46, 2000. https://doi.org/10.1080/08923640009527043

[26] Mohamed, A. Distance higher education in the Arab region: The need for quality assurance frameworks. Online Journal of Distance Learning Administration, vol. 8, no. 1, pp. 1-10, 2005.

[27] Novak, D. Building Quality into Distance Education: Establishing Standards. Pan-Commonwealth Forum on Open Learning, Durban, South Africa, 29 July -2 August 2002.

[28] Oler, D. The Acceptance of Online Graduate Coursework by School Districts in Wisconsin and Illinois. Unpublished master dissertation, University of Wisconsin-Stout, USA, 2006.

[29] Parker, K., Lenhart, A. \& Moore, K. The Digital Revolution and Higher Education: College Presidents, Public Differ on Value of Online Learning. Pew Social \& Demographic Trends, 2011. Available online at www.pewsocialtrends.org.

[30] Phipps, R. \& Merisotis, J. What's the Difference: A Review of Contemporary Research on the Effectiveness of Distance Learning in Higher Education, Institute for Higher Education Policy, Washington, D. C., 1999.

[31] Raj, S. \& Al-Alawneh, M. A Perspective on Online Degrees Vs. Face-to-Face in the Academic Field. The Fifth Conference of Learning International Networks Consortium (LINC), Massachusetts, USA, 23 - 26 May, 2010.

[32] Sadik, A. Directions for Future Research in On-line Distance Education. Turkish Online Journal of Distance Education, vol. 4 no. 4, 2003. Available online at https://tojde.anadolu.edu.tr/ tojde12/articles/sadik.htm

[33] Schornack, G, \& Beck, C. Technology for Mind Expansion. Aeronautical University, Scholarly Commons, 2013, available online at http://commons.erau.edu/bollinger-rosado/2003/11th/6.

[34] Sikora, A. A profile of participation in distance education: 1999. 2000. Postsecondary education descriptive analysis reports. National Center for Education Statistics. NCES 2003-017, MPR Associates: Berkeley, CA., 23, 2003.

[35] United Nations. Population and development in the United Nations system. Department of Economic and Social Affairs, Population Division, 2011. Available online at http://www.un.org/esa/ population/unpop.htm.

[36] Verma, S. \& Jin, L. A Flexible, Low Cost Approach to Conduct Online Surveys Using Open Source Software. Proceedings of Americas Conference on Information Systems. Omaha, Nebraska, USA, 11- 14 August, 2005.

\section{AUTHOR}

Dr. Alaa Sadik (alaasadik@svu.edu.eg) is an associate professor of educational technology at South Valley University, Egypt. He received his Ph.D. degree from the University of Hull, United Kingdom, in 2003. He also worked as an assistant professor at Sultan Qaboos University between 2006 and 2016 . He has more than 10 years of experience in teaching and research, in the field of elearning, distance education, and multimedia and has published many papers in refereed Journals and International conferences.

Submitted 08 July 2016. Published as resubmitted by the author 22 September 2016. 